\title{
Blockade of Nociceptin/Orphanin FQ Receptor Signaling in Rat Substantia Nigra Pars Reticulata Stimulates Nigrostriatal Dopaminergic Transmission and Motor Behavior
}

\author{
Matteo Marti, ${ }^{1}$ Flora Mela, ${ }^{1}$ Carlo Veronesi, ${ }^{2}$ Remo Guerrini, ${ }^{3}$ Severo Salvadori, ${ }^{3}$ Mauro Federici, ${ }^{4}$ Nicola B. Mercuri, \\ Anna Rizzi, ${ }^{1}$ Gianfranco Franchi, ${ }^{2}$ Lorenzo Beani, ${ }^{1}$ Clementina Bianchi, ${ }^{1}$ and Michele Morari ${ }^{1}$ \\ ${ }^{1}$ Department of Experimental and Clinical Medicine, Section of Pharmacology, and Neuroscience Center, ${ }^{2}$ Department of Biomedical Sciences and \\ Advanced Therapies, Section of Human Physiology, and ${ }^{3}$ Department of Pharmaceutical Sciences and Biotechnology Center, University of Ferrara, 44100 \\ Ferrara, Italy, and ${ }^{4}$ Instituto di Ricovero e Cura a Carattere Scientifico Fondazione Santa Lucia, 00179 Rome, Italy
}

A multidisciplinary approach was followed to investigate whether the opioid-like peptide nociceptin/orphanin FQ (N/OFQ) regulates the nigrostriatal dopaminergic pathway and motor behavior. Nigrostriatal dopaminergic cells, which express N/OFQ peptide (NOP) receptors, are located in the substantia nigra pars compacta and extend their dendrites in the substantia nigra pars reticulata, thereby modulating the basal ganglia output neurons. In vitro electrophysiological recordings demonstrated that N/OFQ hyperpolarized the dopaminergic cells of the substantia nigra pars compacta and inhibited their firing activity. In vivo dual-probe microdialysis showed that N/OFQ perfused in the substantia nigra pars reticulata reduced dopamine release in the ipsilateral striatum, whereas UFP-101 $\left(\left[\mathrm{Nphe}^{1}{ }^{1}, \mathrm{Arg}^{14}{ }^{14} \mathrm{Lys}^{15}\right] \mathrm{N} / \mathrm{OFQ}(1-13)-\mathrm{NH}_{2}\right.$ ) (a selective NOP receptor peptide antagonist) stimulated it. N/OFQ microinjected in the substantia nigra pars reticulata impaired rat performance on a rotarod apparatus, whereas UFP-101 enhanced it. Electromyography revealed that N/OFQ and UFP-101 oppositely affected muscle tone, inducing relaxation and contraction of triceps, respectively. The selective NOP receptor nonpeptide antagonist J-113397 (1-[3R,4R)-1-cyclooctylmethyl-3-hydroxymethyl-4-piperidyl]-3-ethyl-1,3-dihydro-2H benzimidazol-2-one), either injected intranigrally or given systemically, also elevated striatal dopamine release and facilitated motor activity, confirming that these effects were caused by blockade of endogenous N/OFQ signaling. The inhibitory role played by endogenous N/OFQ on motor activity was additionally strengthened by the finding that mice lacking the NOP receptor gene outperformed wild-type mice on the rotarod. We conclude that NOP receptors in the substantia nigra pars reticulata, activated by endogenous N/OFQ, drive a physiologically inhibitory control on motor behavior, possibly via modulation of the nigrostriatal dopaminergic pathway.

Key words: dopamine release; J-113397; substantia nigra; motor activity; UFP-101; microdialysis; nociceptin/orphanin FQ; N/OFQ

\section{Introduction}

The opioid-like peptide nociceptin/orphanin FQ (N/OFQ) (Meunier et al., 1995; Reinscheid et al., 1995) modulates pain perception, mood, reward, learning and memory, food intake, and locomotion via activation of the N/OFQ peptide (NOP) receptor (Cox et al., 2000). N/OFQ and its receptor are diffusely expressed in the brain, and evidence for heterogeneity of N/OFQ sites, possibly representing splice variants or posttranslational modifications of the NOP receptor, has been presented (Calò et al., 2000; Mogil and Pasternak, 2001). The pharmacology of the N/OFQ-NOP receptor system has been extensively characterized by means of selective NOP receptor ligands (Zaveri, 2003). Conversely, less is known on the physiology of endogenous N/OFQ,

\footnotetext{
Received March 17, 2004; revised May 25, 2004; accepted May 25, 2004.

This work was supported by Grant Cofin 2002 (C.B.) from the Italian Ministry of the University and by grants from the University of Ferrara (ex-60\%) and Cassa di Risparmio di Ferrara Foundation (M. Morari).

Correspondence should be addressed to Michele Morari, Department of Experimental and Clinical Medicine, Section of Pharmacology, and Neuroscience Center, University of Ferrara, via Fossato di Mortara 17-19, 44100 Ferrara, Italy. E-mail: m.morari@unife.it.

DOI:10.1523/JNEUROSCI.0987-04.2004

Copyright $\odot 2004$ Society for Neuroscience $\quad 0270-6474 / 04 / 246659-08 \$ 15.00 / 0$
}

possibly because of the lack of potent and selective antagonists, which only recently have been developed: the peptide UFP-101 ([Nphe ${ }^{1}, \operatorname{Arg}^{14}{ }^{14}$ Lys $\left.^{15}\right] \mathrm{N} / \mathrm{OFQ}(1-13)-\mathrm{NH}_{2}$ ) (Calò et al., 2002) and the nonpeptide $\mathrm{J}-113397$ (1-[3R,4R)-1-cyclooctylmethyl3-hydroxymethyl-4-piperidyl]-3-ethyl-1,3-dihydro-2H benzimidazol-2-one) (Kawamoto et al., 1999; Ozaki et al., 2000). Thus, although supraspinal administration of high doses of N/OFQ consistently impaired motor activity in rodents, endogenous N/OFQ does not tonically regulate spontaneous locomotion because selective NOP receptor antagonists (Noda et al., 1998; Calò et al., 2000, 2002; Kuzmin et al., 2004) or deletion of the NOP receptor gene ( $\mathrm{NOP}^{-1-}$ mice) failed to affect motor phenotype (Nishi et al., 1997; Murphy et al., 2002; Gavioli et al., 2003; Koizumi et al., 2004). However, daily intracerebroventricular injections of an antisense oligonucleotide to proN/OFQ induced hyperlocomotion in rats (Candeletti and Ferri, 2000), challenging this view. Moreover, endogenous N/OFQ regulation of locomotion under dynamic conditions (e.g., during motor tasks) was not investigated.

Consistent with NOP receptor expression onto mesencephalic dopaminergic (DAergic) neurons (Maidment et al., 2002; 
Norton et al., 2002), motor-depressant actions of N/OFQ have been related to inhibition of the mesoaccumbal DAergic pathway (Murphy et al., 1996; Murphy and Maidment, 1999). However, N/OFQ may also inhibit the nigrostriatal DAergic pathway because it reduced striatal ${ }^{3} \mathrm{H}$-DA release in vitro (Flau et al., 2002), striatal DOPAC content in vivo (Shieh and Pan, 1998), and, when perfused into the substantia nigra $(\mathrm{SN})$ pars reticulata $(\mathrm{SNr})$, facilitated glutamate release via $\mathrm{D}_{2}$ receptor-mediated mechanisms (Marti et al., 2002a). It is known that the opioid system regulates motor activity, at least partly, via the nigrostriatal pathway: $\mu$ and $\delta$ receptor agonists stimulate locomotion and the nigrostriatal transmission, whereas $\kappa$ receptor agonists inhibit both (Mansour et al., 1995). Thus, the N/OFQergic modulation of the nigrostriatal neurons may be behaviorally relevant.

The present study was aimed to investigate whether (1) exogenous N/OFQ inhibits the nigrostriatal DAergic pathway and motor behavior and (2) endogenous N/OFQ tonically activates $\mathrm{SNr}$ NOP receptors. Electrophysiological recordings were performed to study nigral DAergic cell activity in vitro, whereas dual probe microdialysis, a rotarod apparatus, and electromyography (EMG) were used to monitor striatal DA release, activity-induced locomotion, and muscle tone in vivo, respectively. The role of endogenous N/OFQ was investigated by using UFP-101 and $\mathrm{J}-113397$ and by evaluating motor activity of $\mathrm{NOP}^{-1-}$ mice.

Parts of this work has been published previously in abstract form (Marti et al., 2003a).

\section{Materials and Methods}

Male Sprague Dawley rats (300-350 gm; Stefano Morini, Reggio Emilia, Italy) were used in the study. The experimental protocols were approved by Ethical Committee of the University of Ferrara, and adequate measures were taken to minimize animal pain and discomfort.

Electrophysiology. Horizontal slices of ventral midbrain (300 $\mu \mathrm{m}$ thick) were prepared and maintained as described previously (Mercuri et al., 1995). Borosilicate microelectrodes filled with $2 \mathrm{M} \mathrm{NaCl}(5-10 \mathrm{M} \Omega$ ) were used to record single DA neurons extracellularly (see Fig. $1 A$ ) and with 2 $\mathrm{M} \mathrm{KCl}(40-60 \mathrm{M} \Omega$ ) to record intracellularly (see Fig. $1 B$ ) in the SN pars compacta $(\mathrm{SNc})$. Neurons were identified as DAergic using well established electrophysiological and pharmacological criteria (Mercuri et al., 1995; Pucak and Grace 1996; Shepard and Connelly, 1999). The voltage signals were obtained by an amplifier (Axoclamp-2 B; Axon Instruments, Foster City, CA), digitized using a Digidata $1322 \mathrm{~A}$ (Axon Instruments) analog-to-digital interface and Axoscope software (Axon Instruments) running on an IBM-compatible computer, and saved for off-line analysis.

Microinjection technique. A guide-injection cannula (outer diameter, $0.55 \mathrm{~mm}$ ) was stereotaxically implanted under isoflurane anesthesia 0.50 $\mathrm{mm}$ above the right $\mathrm{SNr}$ (anteroposterior, 5.5; mediolateral, 2.2; ventrodorsal, 7.3 from bregma) (Paxinos and Watson, 1982). Seven days after surgery, compounds were injected $(0.5 \mu$ l volume $)$ through a stainlesssteel injector (outer diameter, $0.30 \mathrm{~mm}$ ) protruding $1 \mathrm{~mm}$ beyond the cannula tip. At the end of each experiment, the placement of the probes was verified by microscopic examination.

Microdialysis technique. Two concentric probes were stereotaxically implanted under isoflurane anesthesia in the right dorsolateral striatum (DLS) (3 mm length) and ipsilateral SNr (1 mm length), as described previously (Marti et al., 2002b). Forty-eight hours after surgery, the microdialysis probes were perfused at a flow rate of $3 \mu \mathrm{l} / \mathrm{min}$ with a modified Ringer's solution (in mM: $1.2 \mathrm{CaCl}_{2}, 2.7 \mathrm{KCl}, 148 \mathrm{NaCl}$, and 0.85 $\mathrm{MgCl}_{2}$ ), and samples were collected every $15 \mathrm{~min}$, starting $6 \mathrm{hr}$ after the onset of probe perfusion. In vitro DA recovery for the $3 \mathrm{~mm}$ probe was $12 \pm 2 \%$.

Endogenous DA analysis. DA was measured by means of reversedphase HPLC coupled to electrochemical detection. Briefly, $27 \mu$ l samples were injected onto a 5-C18 Chromsep analytical column perfused at a flow rate of $0.4 \mathrm{ml} / \mathrm{min}$ (Beckman 118 pump; Beckman Instruments,
Table 1. Rotarod training tasks in rats

\begin{tabular}{lllll}
\hline & First speed & Second speed & Third speed & Fourth speed \\
\hline Session 1 $\left(t_{0}\right)$ & $94.2 \pm 1.8 \%$ & $81.0 \pm 3.7 \%$ & $64.2 \pm 4.4 \%$ & $41.7 \pm 4.2 \%$ \\
Session 2 $\left(t_{50}\right)$ & $91.6 \pm 2.6 \%$ & $80.1 \pm 3.6 \%$ & $64.4 \pm 4.2 \%$ & $43.3 \pm 4.3 \%$ \\
Session 3 $\left(t_{100}\right)$ & $92.5 \pm 2.4 \%$ & $81.9 \pm 3.5 \%$ & $61.4 \pm 4.4 \%$ & $43.1 \pm 4.1 \%$
\end{tabular}

Naive, drug-free rats were trained to perform on the rotarod at four increasing speeds until their motor performance was reproducible along three consecutive sessions, performed at $t_{0}$ (session 1 or control session) or after $50 \mathrm{~min}\left(t_{50}\right.$ session 2$)$ and $100 \mathrm{~min}\left(t_{100}\right.$, session 3$)$. Speeds were selected to obtain progressive inhibition of rat performance down to $\sim 40 \%$ of maximum performance (usually $25,30,35$, and $40 \mathrm{rpm}$; cutoff time of $180 \mathrm{sec}$ ). Data are expressed as percentage means \pm SEM of maximum response (45-50 determinations).

Fullerton, CA) with a mobile phase containing $75 \mathrm{mM} \mathrm{NaH}_{2} \mathrm{PO}_{4}, 20 \mu \mathrm{M}$ EDTA, $0.01 \%$ triethylamine, $1.5 \mathrm{~mm}$ SDS, $10 \%$ methanol, and $16 \%$ acetonitrile, adjusted to $\mathrm{pH} 5.6$ with $\mathrm{NaOH}$. DA was detected by means of an electrochemical detector (Coulochem II model 5200; ESA, Chelmsford, MA) set at $+175 \mathrm{mV}$. The limit of detection for DA was $10 \mathrm{fmol} / \mathrm{sample}$.

Studies on motor behavior. The fixed-speed rotarod (FSRR) test (Rozas et al., 1997; Rustay et al., 2003) was used to investigate the effects of NOP receptor ligands on physiologically stimulated motor activity. Rats were handled for 1 week by the same operator to reduce stress and trained for additional $10 \mathrm{~d}$ on a rotating spindle $(7.6 \mathrm{~cm}$ diameter) until their motor performance became reproducible. To detect both facilitatory and inhibitory effects on motor activity (Rustay et al., 2003), a specific protocol was developed: rats were tested $\left(t_{0}\right)$ at four increasing speeds (usually 25, 30, 35 , and $40 \mathrm{rpm} ; 180 \mathrm{sec}$ each), causing a progressive decrement of performance to $\sim 40 \%$ of the maximal response (i.e., the experimental cutoff time) (Table 1). A similar response could be reproduced by applying this protocol 50 and $100 \mathrm{~min}$ later $\left(t_{50}\right.$ and $t_{100}$ ) (Table 1 ). Thus, to quantify drug effect on motor behavior, drugs were administered 10 min before $t_{50}$, and rotarod performance (total time spent on the rotarod) was calculated at $t_{50}$ and $t_{100}$ (i.e., 10 and $60 \mathrm{~min}$ after injection) as a percentage of control $\left(t_{0}\right)$ performance.

Whenever pharmacological treatment was associated with contralateral turning, rotational behavior was specifically measured. Rats were left to habituate in circular bowls for $20 \mathrm{~min}$ before the beginning of the test. Contralateral turns (i.e., turns in direction opposite to the injection side) were counted every $5 \mathrm{~min}$, from $15 \mathrm{~min}$ before to $90 \mathrm{~min}$ after drug injection.

EMG recordings. Bipolar electrodes (Teflon-coated stainless-steel wire; Clark Electromedical Instruments, Pangbourne, UK) were bilaterally implanted in the triceps muscles under ketamine anesthesia $(100 \mathrm{mg} / \mathrm{kg})$. The distal end of the electrodes (with $\sim 300 \mu \mathrm{m}$ of the insulation removed) were sutured to the belly of the muscle. The proximal end of the wire was joined to a five pin socket and secured with dental cement on the skull of the animals. Experiments were performed $7 \mathrm{~d}$ after surgery in unrestrained awake animals placed in a cage. EMG activity was recorded bilaterally $(20 \mathrm{sec})$, before $\left(t_{0}\right)$ or $10\left(t_{10}\right)$ and $60\left(t_{60}\right)$ min after intranigral injection of NOP receptor ligands. The EMG signals were amplified (P5 amplifier; Grass Instruments, Quincy, MA), filtered (bandpass, $30 \mathrm{~Hz}$ to $30 \mathrm{kHz}$ ), monitored on a storage oscilloscope (model 5113; Tektronix, Wilsonville, OR), and acquired by analog-to-digital interface for off-line analysis (CED 1401 and Spike2; Cambridge Electronic Design, Cambridge, UK). Then, the EMGs were rectified, and the area of the first 10 sec of activity was determined. The area-under-the-curve (AUC) value of the rectified EMG provided better estimate of the electrical activity of muscle fibers than the peak-to-peak amplitude (Buchthal and Kuhl, 1979). AUC values were normalized and expressed as a percentage of baseline $t_{0}$ values (see Fig. 6).

Motor behavior in $\mathrm{NOP}^{+/+}$and $\mathrm{NOP}^{-/-}$mice. $\mathrm{NOP}^{+/+}$and $\mathrm{NOP}^{-1-}$ mice $(25-30 \mathrm{gm})$ were generated on a mixed C57BL/6J and 129 genetic background (Nishi et al., 1997) and backcrossed with CD1 mice (Bertorelli et al., 2002) for nine generations, which would guarantee that $>95 \%$ of their genetic background is of the CD1 type. Animals were genotyped by PCR. Spontaneous locomotor activity was measured in nonhabituated male mice by using Ugo Basile (Comerio, Italy) activity cages (Rizzi et al., 2001). The total number of impulses were recorded every $5 \mathrm{~min}$ for $30 \mathrm{~min}$. The FSRR test was used to investigate the motor performance of nonhabituated mice and the adaptive changes occurring 
A

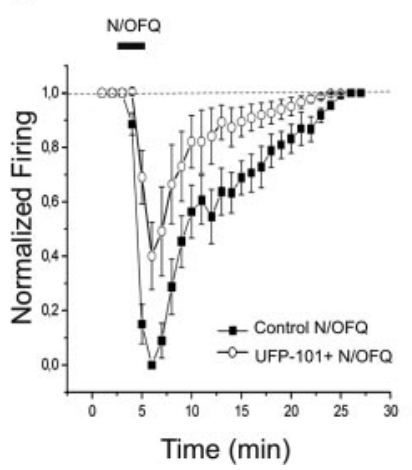

B

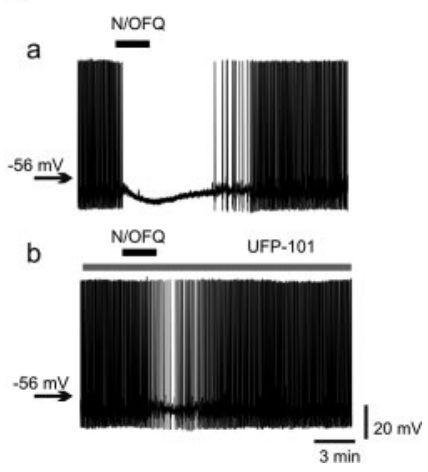

Figure 1. Effects of N/OFQ and UFP-101 on activity of SNc DAergic neurons. A, Extracellular recordings of SNc DAergic neurons. N/OFQ ( $100 \mathrm{~nm} ; 3 \mathrm{~min}$; black bar) reduced the firing rate of SNc DAergic neurons, and UFP-101 (1 $\mu \mathrm{m})$ antagonized its effect. In the presence of UFP-101, not only the amplitude but also the duration of the firing inhibition was reduced. Perfusion with UFP-101 started 7-10 min before N/OFQ and continued until the end of experiment. The firing rates of neurons after drug application were normalized to the control firing rate in the same neuron. Points represent means \pm SEM of seven experiments. $B$, Intracellular recordings of a DAergic neuron. N/OFQ (100 nм; 3 min; black bar) hyperpolarized the membrane and caused firing inhibition (a). N/OFQ-induced effects were clearly depressed by UFP-101 $(1 \mu \mathrm{M})(b)$. Perfusion with UFP-101 started 7-10 min before N/OFQ and continued until the end of experiment (gray bar).

after repeated motor tasks. Each mouse was tested on the rotarod at a wide range of increasing speeds (5-55 rpm), and the time spent on the rod was calculated (180 sec cutoff time). This protocol was performed daily (from 9:00 A.M. to 12:00 P.M.) for 4 consecutive days.

Data presentation and statistical analysis. DA release has been expressed as percentage \pm SEM of basal values (calculated as mean of the two samples before the treatment). Motor performance of rats has been presented as percentage \pm SEM of the control session, whereas motor performance of mice has been presented in absolute values (in seconds). Statistical analysis was performed (Prism software; GraphPad Software, San Diego, CA) on AUC values (expressed in arbitrary units) by ANOVA, followed by the Newman-Keuls test for multiple comparisons. $p$ values $<0.05$ were considered to be statistically significant.

Materials. N/OFQ and UFP-101 were prepared as described previously (Guerrini et al., 2000). J-113397 was synthesized in our laboratories as a racemic mixture (De Risi et al., 2001). All drugs were freshly dissolved in Ringer's or isosmotic saline solution.

\section{Results}

\section{Effects of NOP receptor ligands on the activity of SNc} DAergic neurons

To test whether nigral NOP receptors modulate the activity of SNc DAergic neurons, the effects of NOP receptor ligands were first examined using intracellular recordings in vitro (Fig. 1). DAergic cells were spontaneously firing at a rate of $1.3 \mathrm{~Hz}$ (range, $0.5-3 \mathrm{~Hz}$ ) and had a spike width of $>1.2 \mathrm{msec}$. N/OFQ (100 nM) caused membrane hyperpolarization $(6.5 \pm 1.2 \mathrm{mV} ; n=5)$ that resulted in depression of action potential discharge. The firing rate recovered to control conditions within 15-20 min from drug washout (Fig. 1A). The specificity of N/OFQ action was investigated by using UFP-101. Perfusion with UFP-101 (1 $\mu \mathrm{M})$ did not change the rate and pattern of firing discharge. However, it reduced by $60 \pm 12 \%(p<0.03$; paired $t$ test; $n=5)$ the extent and time course of (100 nM) N/OFQ-induced firing inhibition and membrane hyperpolarization (Fig. $1 A, B)$. UFP-101 did not counteract inhibition induced by higher (300 nM) N/OFQ concentrations. However, when the agonist was discontinued, the inhibitory action of N/OFQ washed faster in the presence of UFP-
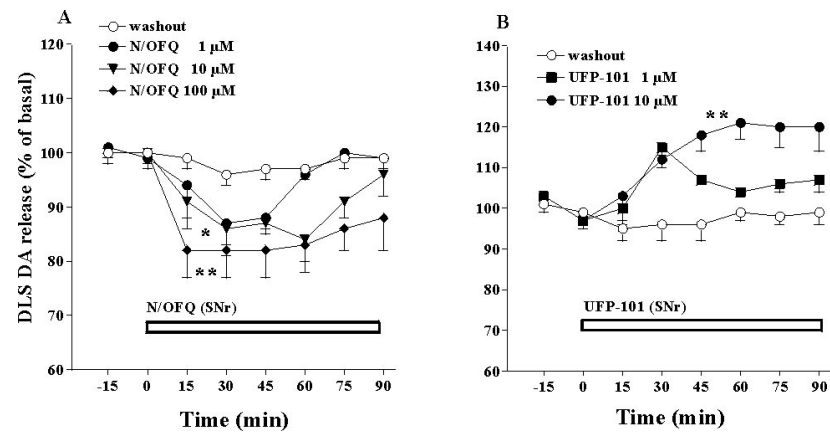

Figure 2. Effect of N/OFQ and UFP-101 on striatal DA release. $A$, Effect of local perfusion with N/OFQ (1-100 $\mu \mathrm{m} ; 90 \mathrm{~min}$; open bar) in the SNr of awake rats on DA release in the ipsilateral DLS. Basal DA (in nanomolar) and AUC (in arbitrary units) values were, respectively, as follows: $1.70 \pm 0.31,7283 \pm 137.3$ (washout; $n=9), 1.03 \pm 0.26,6887 \pm 69.5(1 \mu \mathrm{m} \mathrm{N} /$ OFQ $; n=$ 6), $1.88 \pm 0.31,6599 \pm 152.1(10 \mu \mathrm{M} \mathrm{N} / \mathrm{OFQ} ; n=7), 1.96 \pm 0.33$, and $6219 \pm 328.5(100$ $\mu \mathrm{m} \mathrm{N} / 0 \mathrm{FQ} ; n=5$ ). $B$, Effect of local perfusion with UFP-101 (1 and $10 \mu \mathrm{m} ; 90 \mathrm{~min}$; open bar) in the SNr of awake rats on DA release in the ispilateral DLS. Basal DA (in nanomolar) and AUC (in arbitrary units) values were, respectively, as follows: $1.59 \pm 0.31,7343 \pm 187.1$ (washout; $n=6) ; 1.35 \pm 0.15,7701 \pm 266.8(1 \mu \mathrm{M}$ UFP-101; $n=4), 1.43 \pm 0.30$, and $8728 \pm 219.8$ $(10 \mu \mathrm{M}$ UFP- $101 ; n=6)$. Data are expressed as percentages \pm SEM of basal pretreatment levels (calculated as the mean of the 2 samples before the treatment). ${ }^{*} p<0.05 ;{ }^{* *} p<0.01$, significantly different from washout.

101 than in control conditions ( $p<0.05 ; n=5$ as measured at 4 , 8 , and 12 min wash; data not shown).

\section{Effect of SNr perfusion with NOP receptor ligands on DA release in the DLS}

To test whether nigral NOP receptors modulate the nigrostriatal dopaminergic transmission, NOP receptor ligands were perfused (90 $\mathrm{min}$ ) through a microdialysis probe implanted in the $\mathrm{SNr}$, and DA was recovered via another probe implanted in the ipsilateral DLS. Basal extracellular DA levels in the DLS were $1.65 \pm$ $0.35 \mathrm{nM}(n=16)$ and were inhibited by N/OFQ $\left(F_{(3,23)}=6.79\right.$; $p=0.0019)$ (Fig. $2 A)$, perfused intranigrally at $10(p<0.05)$ and $100(p<0.01) \mu \mathrm{M}$ (maximum reduction to $\sim 84$ and $\sim 82 \%$ of basal levels, respectively). On the contrary, intranigral perfusion with UFP-101 increased striatal DA release $\left(F_{(2,13)}=11.8 ; p=\right.$ $0.0012)$ (Fig. $2 B)$ at $10 \mu \mathrm{M}(p<0.01)$. At this concentration, UFP-101 also prevented the inhibition brought about by $10 \mu \mathrm{M}$ N/OFQ. Indeed, N/OFQ effect in the presence of UFP-101 (AUC, $7431 \pm 369 ; n=5$ ) was not different from control (AUC, $7190 \pm$ $169 ; n=6 ; p=0.54$; data not shown).

\section{Effect of SNr injections of NOP receptor ligands on motor behavior}

In view of the ability of N/OFQ and UFP-101 to oppositely modulate striatal DA release, the effect of intranigral injections of NOP receptor ligands on the rotarod performance were assessed (Figs. 3, 4). N/OFQ depressed motor performance at $10\left(F_{(4,28)}=\right.$ 107.5; $p<0.0001)$ (Fig. $3 A)$ and $60\left(F_{(4,19)}=11.16 ; p<0.0001\right)$ min, postinjection time. At $10 \mathrm{~min}$ postinjection time, $0.1 \mathrm{nmol}$ of N/OFQ produced a significant $(\sim 40 \%)$ inhibition, whereas 10 nmol of N/OFQ abolished motor activity, with rats showing marked impairment of motor coordination and flaccid muscle tone. UFP-101 alone $(0.1-30 \mathrm{nmol})$ biphasically regulated motor performance $\left(F_{(4,28)}=73.75 ; p<0.0001\right)$ (Fig. 3B). Significant increases were observed at 1 and $10 \mathrm{nmol}$ UFP-101 $(\sim 47$ and $\sim 76 \%$, respectively; $p<0.05$ ), whereas marked impairment was observed at $30 \mathrm{nmol}(\sim 97 \%$; $p<0.01)$. At $30 \mathrm{nmol}$, however, UFP-101 induced complex changes in motor behavior, such as 

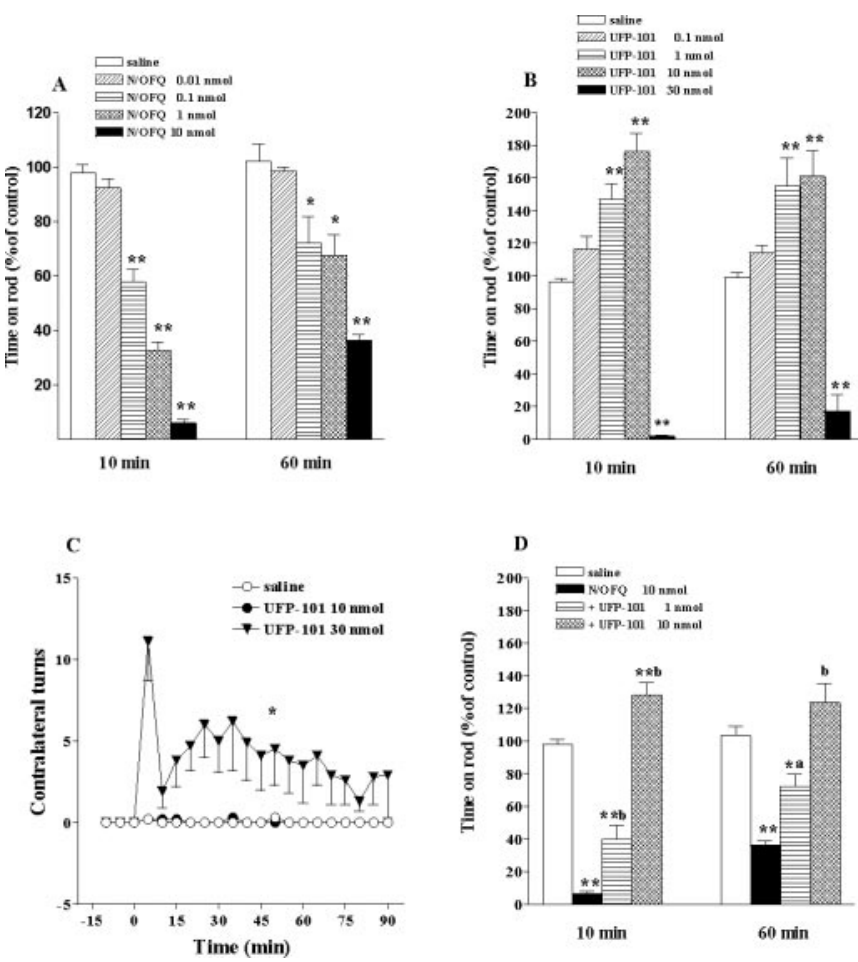

Figure 3. Effect of N/OFQ and UFP-101 on motor activity. Effect of N/OFQ (0.01-10 nmol) $(A)$ and UFP-101 $(0.1-30 \mathrm{nmol})(B)$ or the combination of both $(D)$ in the $\mathrm{SNr}$ on the rotarod performance in rats. Each experiment consisted of three different sessions: a control session, followed by two other sessions performed 10 and $60 \mathrm{~min}$ after saline or NOP receptor ligand injections (see Materials and Methods). Data are expressed as percentages \pm SEM of motor activity in the control session and are means of $6-12$ determinations. In C, contralateral turning induced by UFP-101 is shown. Total number of turns in 90 min were $1.36 \pm 0.15(n=11)$, $1.37 \pm 0.18(n=8)$, and $69.8 \pm 23.9(n=16)$ for saline and the 10 and $30 \mathrm{nmol}$ UFP-101 groups, respectively. ${ }^{*} p<0.05 ;{ }^{* *} p<0.01$, significantly different from saline. ${ }^{a} p<0.05$; ${ }^{\mathrm{b}} p<0.01$, significantly different from N/OFQ.
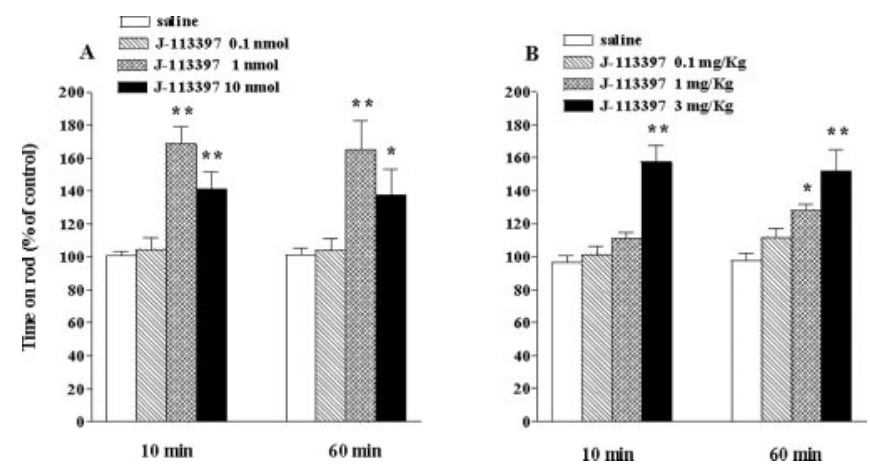

Figure 4. Effect of J-113397 on motor activity. Effect of J-113397 injected ( $0.1-10 \mathrm{nmol})$ in the $\mathrm{SNr}(A)$ or systemically administered $(0.1-3 \mathrm{mg} / \mathrm{kg}$, i.p.) (B) on the rotarod performance in rats. Each experiment consisted of three different sessions: a control session, followed by two other sessions performed 10 and $60 \mathrm{~min}$ after saline or UFP-101 injections (see Materials and Methods). Data are expressed as percentages \pm SEM of motor activity in the control session and are means of $6-10$ determinations. ${ }^{*} p<0.05 ;{ }^{* *} p<0.01$, significantly different from saline.

spontaneous contralateral turning $(p<0.05)$ (Fig. $3 C)$ and increase in tonic muscle activity (see Figs. 6,7 ), which may have hampered correct execution of the task and caused dramatic motor incoordination (Rozas et al., 1997). UFP-101 motor effects were still evident $60 \mathrm{~min}$ after injection $\left(F_{(4,28)}=32.28 ; p<\right.$ $0.0001)$. To investigate the selectivity of N/OFQ action, intranigral coinjections of N/OFQ and UFP-101 were performed. As
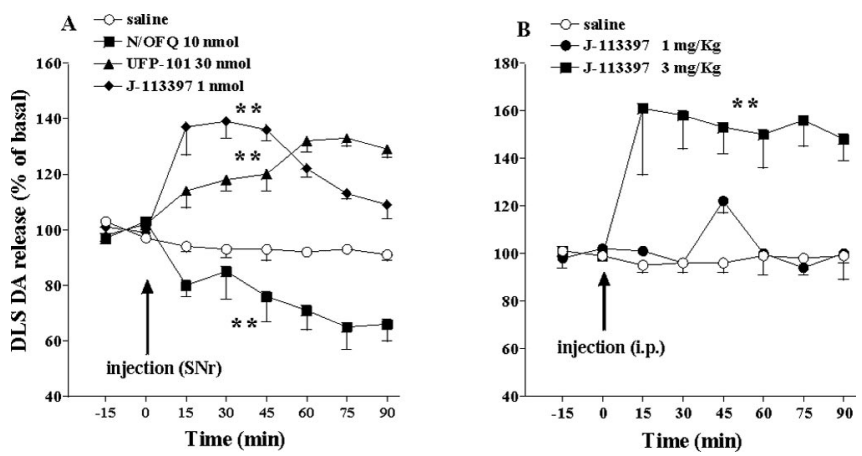

Figure 5. Effect of N/OFQ, UFP-101, and J-113397 on striatal DA release. Effects of N/OFQ (10 nmol), UFP-101 ( $30 \mathrm{nmol})$, and J-113397 ( $1 \mathrm{nmol})$ injection in the SNr ( A) or J-113397 systemic administration (1-3 mg/kg, i.p.) (B) on spontaneous DA release in the DLS. A, Basal DA (in nanomolar) and AUC (in arbitrary units) values were: $1.52 \pm 0.17,7001 \pm 112.8$ (saline; $n=$ 10), $1.48 \pm 0.16,5460 \pm 374.4(10 \mathrm{nmol}$ of N/OFQ $; n=5), 2.13 \pm 0.40,9363 \pm 252(30 \mathrm{nmol}$ of UFP-101; $n=5), 1.53 \pm 0.12$, and $9480 \pm 173.5(1 \mathrm{nmol}$ of J-113397; $n=5)$. B, Basal DA (in nanomolar) and AUC (in arbitrary units) values were as follows: $1.48 \pm 0.21,7245 \pm 195.6$ (saline; $n=5), 1.25 \pm 0.10,7663 \pm 219.9(1 \mathrm{mg} / \mathrm{kg} \mathrm{J}-113397 ; n=4), 1.52 \pm 0.32$, and $11594 \pm 956(3 \mathrm{mg} / \mathrm{kg} \mathrm{J}-113397 ; n=4)$. Data are expressed as percentages \pm SEM of basal pretreatment levels (calculated as the mean of the 2 samples before the treatment). ${ }^{* *} p<$ 0.01 , significantly different from saline.

shown in Figure 3D, 1 nmol of UFP-101 attenuated the inhibitory effect of $10 \mathrm{nmol}$ of N/OFQ, whereas $10 \mathrm{nmol}$ of UFP-101 prevented it.

To confirm that NOP receptor blockade in the $\mathrm{SNr}$ resulted in facilitation of motor activity, the nonpeptide NOP receptor antagonist J-113397 was tested (Fig. 4). J-113397 injected into the $\mathrm{SNr}$ facilitated motor performance both at $10\left(F_{(3,18)}=24.43\right.$; $p<0.0001)$ and $60\left(F_{(3,17)}=16.43 ; p<0.0001\right)$ min, postinjection time (Fig. $4 A$ ). The effect was significant for the 1 and 10 nmol doses $(p<0.01)$. Likewise, J-113397 systemically (intraperitoneally) administered elevated motor performance at 10 $\left(F_{(3,23)}=20.22 ; p<0.0001\right)$ and $60\left(F_{(3,23)}=11.21 ; p<0.0001\right)$ min, postinjection time (Fig. $4 B$ ). A significant effect was detected at $3 \mathrm{mg} / \mathrm{kg}(p<0.01)$, although a delayed increase was produced by the $1 \mathrm{mg} / \mathrm{kg}$ dose $(p<0.05)$.

\section{Effect of SNr injection of NOP receptor ligands on DA release in the DLS}

To investigate whether changes of motor behavior were associated with changes of striatal DA release, NOP receptor ligands were injected into the $\mathrm{SNr}$, and DA release was monitored in the ipsilateral DLS. Ten nanomoles of N/OFQ depressed DA release (maximum inhibition of $\sim 35 \%$ ), whereas $30 \mathrm{nmol}$ of UFP-101 and $1 \mathrm{nmol}$ of J-113397 facilitated it (maximum increase of $\sim 32$ and $\sim 39 \% ; p<0.01$ ) (Fig. $5 A$ ). Systemic J-113397 administration (Fig. $5 B$ ) also elevated striatal DA release $\left(F_{(2,9)}=17.19 ; p=\right.$ 0.0008 ) (Fig. $5 B)$ but only at $3 \mathrm{mg} / \mathrm{kg}(\sim 61 \%$; $p<0.01)$.

\section{Effect of SNr injection of NOP receptor ligands on EMG activity}

To quantify the apparent changes of muscle tone caused by intranigral injections of N/OFQ and UFP-101, bilateral EMGs of the rat triceps were recorded (Fig. 6). Ten nanomoles of N/OFQ long-lastingly depressed muscle tone in both triceps of the rat regardless of the side investigated $\left(F_{(3,40)}=6.748, p=0.0009\right.$ and $F_{(3,55)}=226.6, p<0.0001$, for the ipsilateral and contralateral side, respectively). Muscle tone was depressed contralaterally to $\sim 19$ and $\sim 26 \%$ of baseline, 10 and 60 min after injection, respectively (both, $p<0.01$ ), whereas ipsilaterally the effect was less 

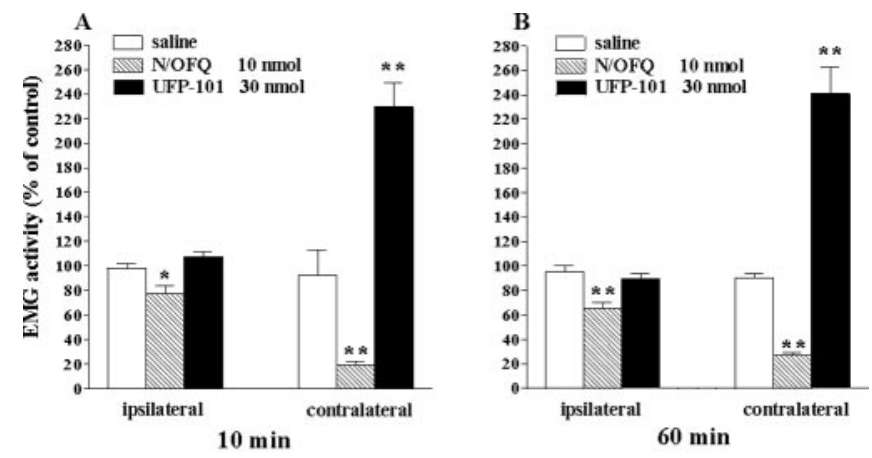

\section{IPSILATERAL}

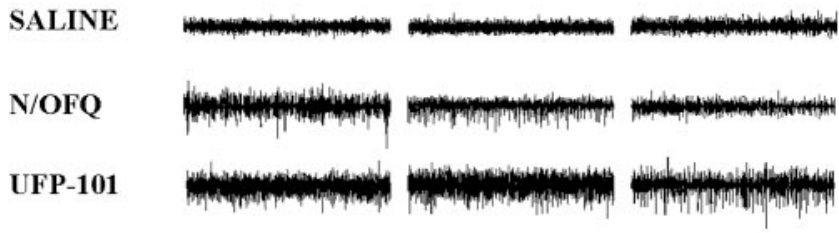

CONTRALATERAL

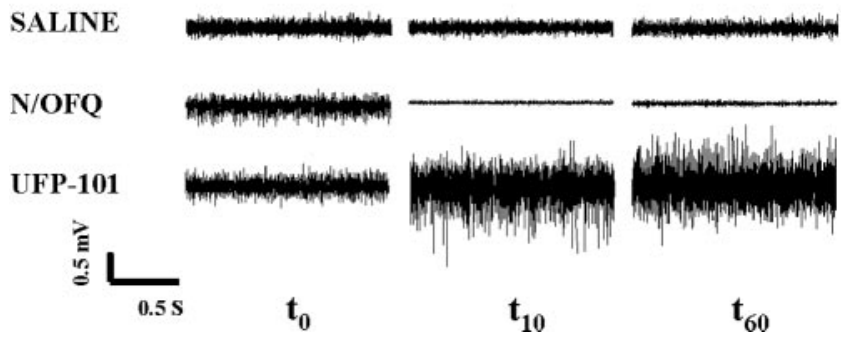

Figure 6. Effects of N/OFQ and UFP-101 on tonic muscle activity. Effects of N/OFQ (10 nmol) and UFP-101 $(30 \mathrm{nmol})$ injection in the substantia nigra pars reticulata of awake rats on EMG activity of triceps muscles contralateral and ipsilateral to the injection side. EMG activity was recorded $10(A)$ and $60(B)$ min after drug or saline injection and is expressed as percentage means \pm SEM of pretreatment control values (8-15 determinations). C, Representative EMG traces of triceps muscle activity after N/OFQ and UFP- 101 injections. Triceps contralateral and ipsilateral to the injection side were recorded at time $0\left(t_{0}\right)$ or $10\left(t_{10}\right)$ and $60\left(t_{60}\right)$ min after drug or saline injections. ${ }^{*} p<0.05 ;{ }^{* *} p<0.01$, significantly different from saline.

marked $(\sim 77$ and $\sim 64 \%$ of baseline; $p<0.05$ and $p<0.01$, respectively). On the contrary, $30 \mathrm{nmol}$ of UFP-101 increased EMG activity in the contralateral $\left(F_{(3,79)}=16.94 ; p<0.0001\right)$ but not ipsilateral triceps. The effect was robust after $10 \mathrm{~min}$ and still unchanged 60 min after injection $(\sim 230$ and $\sim 240 \%$, respectively; both, $p<0.01$ ).

\section{Motor behavior in NOP ${ }^{+/+}$and NOP ${ }^{-/-}$mice}

To additionally strengthen the view that endogenous N/OFQ physiologically controls motor behavior, spontaneous and activity-induced locomotion of $\mathrm{NOP}^{+/+}$and $\mathrm{NOP}^{-/-}$mice was tested. $\mathrm{NOP}^{+/+}$and $\mathrm{NOP}^{-/-}$mice showed comparable spontaneous locomotion $(2334 \pm 180$ and $2300 \pm 123$ counts in $30 \mathrm{~min}$, respectively) (Table 2 ) but performed differently on the rotarod (Fig. 7). Rotarod activity of $\mathrm{NOP}^{+/+}$mice on day 1 progressively decayed to zero in the 5-35 rpm speed range (Fig. 7A), and total time spent on the rod was $514 \pm 38 \mathrm{sec}$ (Fig. 7C). Motor ability improved with exercise $\left(F_{(7,71)}=20.57 ; p<0.0001\right)$, as shown by rightward shift of the time $X$ rpm curve and increase in performance in subsequent tests (Fig. 7C). Motor performance of $\mathrm{NOP}^{-1-}$ mice on day 1 decayed to zero in a wider range of speeds (5-50 rpm) (Fig. 7B) and was significantly higher than in
$\mathrm{NOP}^{+/+}$mice $(700 \pm 36 \mathrm{sec} ; p<0.05)$ (Fig. $7 C$ ). A progressive improvement of motor ability was observed in the following tests (Fig. 7B), although maximum performance was significantly higher in $\mathrm{NOP}^{-1-}(1229 \pm 79 \mathrm{sec})$ compared with $\mathrm{NOP}^{+/+}$mice $(896 \pm 51 \mathrm{sec} ; p<0.05)$ (Fig. 7C).

\section{Discussion}

N/OFQ application to nigral slices reduced the firing of SN DAergic neurons, whereas N/OFQ injection in the SNr in vivo reduced striatal DA release, rotarod performance, and muscle tone. Blockade of N/OFQ signaling in vivo (either pharmacologically or genetically) produced effects opposite than those of N/OFQ, overall suggesting that exogenous and endogenous N/OFQ inhibit the nigrostriatal DAergic pathway and motor behavior.

SN NOP receptors inhibit the nigrostriatal DAergic pathway Previous studies have shown that intracerebroventricular N/OFQ reduced spontaneous (Murphy et al., 1996; Murphy and Maidment, 1999; Koizumi et al., 2004) and pharmacologically stimulated (Di Giannuario et al., 1999; Lutfy et al., 2001) DA release in the nucleus accumbens but not striatum (Di Giannuario and Pieretti 2000), ruling out an involvement of N/OFQ in the modulation of the nigrostriatal axis. The present finding that intranigral N/OFQ inhibited striatal DA release in a UFP-101sensitive way contradicts this view. In particular, reduction of striatal DA levels after intranigral N/OFQ was comparable with that observed in the nucleus accumbens after intrategmental N/OFQ (Murphy and Maidment, 1999), although it was evident at lower N/OFQ concentrations (10 $\mu \mathrm{M}$ vs $1 \mathrm{mM})$, possibly because of the use of anesthesia in that study. Inhibition of SN DAergic cells, which express NOP receptors (Maidment et al., 2002; Norton et al., 2002), may underlie reduction of striatal DA levels by intranigral N/OFQ because, in line with that found in ventral tegmental area slices (Zheng et al., 2002), SN DAergic cells were inhibited by N/OFQ (via UFP-101-sensitive NOP receptors). Firing inhibition resulted from membrane hyperpolarization, very likely caused by $\mathrm{K}^{+}$channel opening (Zheng et al., 2002). Different from that reported for the mesoaccumbal pathway in the mouse (Koizumi et al., 2004), however, an N/OFQergic inhibitory tone on the nigrostriatal transmission was disclosed because NOP receptor antagonists given into the $\mathrm{SNr}$ facilitated striatal DA release. This facilitation was likely a result of NOP receptor blockade because it was consistently observed with chemically unrelated molecules, delivered to the $\mathrm{SNr}$ via different routes, at doses reported to selectively affect N/OFQ responses (for UFP-101, see Calò et al., 2002; Koizumi et al., 2004; Kuzmin et al., 2004; for J-113397 see, Ozaki et al., 2000; Ueda et al., 2000; McLeod et al., 2001; Lutfy et al., 2002). Tonic N/OFQergic control of the nigrostriatal DAergic transmission was disclosed only in vivo because UFP-101 did not affect firing activity in nigral slices. This is no surprise, because tonic inhibition of SN DAergic neurons mediated by GABA and DA (via GABA $\mathrm{A}_{\mathrm{A}}$ and $\mathrm{D}_{2}$ receptors, respectively) was also observed in vivo (Chiodo and Bunney, 1984; Paladini and Tepper, 1999) but not in vitro (Pinnock, 1984; Lacey et al., 1987; Mercuri et al., 1990).

\section{SN NOP receptors inhibit motor behavior}

Previous studies have shown that N/OFQ inhibited spontaneous (Reinscheid et al., 1995; Devine et al., 1996; Rizzi et al., 2001) cocaine-stimulated (Lutfy et al., 2001) and morphine-stimulated (Di Giannuario et al., 1999; Di Giannuario and Pieretti, 2000) locomotion, whereas Ro 64-6198 [(1S,3aS)-8-2,3,3a,4,5,6hexahydro-1H-phenalen-1-yl)-1-phenyl-1,3,8-triaza-spiro[4.5] 
decan-4-one] (a nonpeptide NOP receptor agonist) induced hypolocomotion (Kuzmin et al., 2004) and impaired rotarod performance (Jenck et al., 2000). The fact that intranigral N/OFQ inhibited rotarod performance and muscle tone extends these findings, indicating that $\mathrm{SNr}$ NOP receptors drive an inhibitory control on motor behavior. These receptors appear to be tonically activated by endogenous N/OFQ, especially under execution of a motor task, because both UFP-101 and J-113397 facilitated the rotarod performance, although only UFP-101 (at high doses) affected spontaneous locomotion. This indicates that exercise-induced activity is more sensitive to blockade of $\mathrm{SNr}$ $\mathrm{N} / \mathrm{OFQ}$ signaling. It is plausible that N/OFQ-sensitive motor pathways come into play during exercise or that, during exercise, endogenous N/OFQ is released in greater amounts than at rest. Studies on $\mathrm{NOP}^{+1+}$ and $\mathrm{NOP}^{-1-}$ mice confirmed the specific involvement of endogenous N/OFQ in the modulation of physiologically stimulated activity. Indeed, although the two genotypes displayed similar spontaneous activity (Nishi et al., 1997; Murphy et al., 2002; Gavioli et al., 2003; Koizumi et al., 2004), $\mathrm{NOP}^{-/-}$mice outperformed $\mathrm{NOP}^{+/+}$mice on the rotarod. It is noteworthy that this difference was significant at the first rotarod challenge and maintained during training, suggesting that greater spatial learning ability and memory reported for $\mathrm{NOP}^{-1-}$ mice (Manabe et al., 1998) were not involved. The mechanisms underlying the greater performance of $\mathrm{NOP}^{-1-}$ mice on the rotarod are presently unknown. A previous study demonstrated that striatal DA release increased during rotarod performance (Bergquist et al., 2003), suggesting that the greater performance of $\mathrm{NOP}^{-1-}$ is a result of greater DA release in the striatum. The finding that $\mathrm{NOP}^{-1-}$ and $\mathrm{NOP}^{+/+}$mice did not display any difference in basal and heroinstimulated striatal DA levels (Murphy et al., 2002; Koizumi et al., 2004), however, may suggest that other mechanisms are involved. In this respect, both DA-dependent and DA-independent mechanisms may underlie motor effects of NOP receptor ligands. Indeed, N/OFQ inhibited both DAergic and GABAergic mesencephalic neurons (Zheng et al., 2002) and reduced accumbal DA release (Murphy and Maidment, 1999) or increased SNr glutamate release (Marti et al., 2002a), partly via bicuculline-sensitive mechanisms.

The complex motor pattern of response (contralateral rotations, rigidity, and motor incoordination) induced by $30 \mathrm{nmol}$ of UFP-101 may indicate that tonic N/OFQ regulation of spontaneous activity can be unveiled, provided a high degree of NOP receptor blockade, leading to asymmetric motor disinhibition, is reached into one SNr. Similar to UFP-101, unilateral injection of morphine into the $\mathrm{SNr}$ also induced contralateral turning, possibly via increased nigrostriatal DAergic transmission (Iwamoto and Way, 1977; Matsumoto et al., 1988; Bontempi and Sharp, 1997; but see Morelli and Di Chiara, 1985) and rigidity, possibly via disinhibition of nigrofugal GABAergic pathways (Turski et al., 1982, 1983). It is therefore possible that high doses of UFP101 , by acting on NOP receptors located on different neuronal subtypes and nigrofugal pathways, affect different parameters of motor behavior. On the other hand, the possibility that high doses of UFP-101 exert aspecific effects (i.e., beyond NOP receptor blockade) cannot be ruled out because UFP-101 has been reported to induce motor effects in $\mathrm{NOP}^{-1-}$ mice (Koizumi et al., 2004). The different motor profile of J-113397 compared with UFP-101 may further support this view, although this difference may also be caused by interaction with NOP receptors bearing different pharmacological properties (Mogil and Pasternak, 2001; Marti et al., 2003b; Kuzmin et al., 2004).

\section{Concluding remarks}

Pharmacological and genetic evidence demonstrated that endogenous N/OFQ inhibits the nigrostriatal DAergic pathway and activity-stimulated locomotion by activating SNr NOP receptors. These data extend previous studies indicating that endogenous N/OFQ tonically modulates neurosecretion (Marti et al., 2002a; Kawahara et al., 2004), firing activity (Albrecht et al., 2001), and, at least under certain conditions, pain (Calò et al., 2000; Ueda et al., 2000; Zaratin et al., 2004), mood (Redrobe et al., 2002; Gavioli et al., 2003), and food intake (Polidori et al., 2000). NOP receptor antagonists may thus be proven effective in relieving hypokinesia under conditions of enhanced nigral N/OFQergic tone. This may be the case in Parkinson's disease. Indeed, DA denervation induced by intranigral injection of 6-hydroxydopamine is associated with increased levels of nigral N/OFQ mRNA (Norton et al., 2002), suggesting that endogenous N/OFQ may contribute to hypokinesia induced by DA loss.

\section{References}

Albrecht D, Bluhdorn R, Siegmund H, Berger H, Calò G (2001) Inhibitory action of nociceptin/orphanin FQ on functionally different thalamic neurons in urethane-anaesthetized rats. Br J Pharmacol 134:333-342.

Bergquist F, Shahabi HN, Nissbrandt H (2003) Somatodendritic dopamine release in rat substantia nigra influences motor performance on the accelerating rod. Brain Res 973:81-91.

Bertorelli R, Bastia E, Citterio F, Corradini L, Forlani A, Ongini E (2002) Lack of the nociceptin receptor does not affect acute or chronic nociception in mice. Peptides 23:1589-1596. 
Bontempi B, Sharp FR (1997) Systemic morphine-induced Fos protein in the rat striatum and nucleus accumbens is regulated by $\mu$ opioid receptors in the substantia nigra and ventral tegmental area. J Neurosci 17:8596-8612.

Buchthal F, Kuhl V (1979) Nerve conduction, tactile sensibility, and the electromyogram after suture or compression of peripheral nerve: a longitudinal study in man. J Neurol Neurosurg Psychiatry 42:436-451.

Calò G, Guerrini R, Rizzi A, Salvadori S, Regoli D (2000) Pharmacology of nociceptin and its receptor: a novel therapeutic target. Br J Pharmacol 129:1261-1283.

Calò G, Rizzi A, Rizzi D, Bigoni R, Guerrini R, Marzola G, Marti M, McDonald J, Morari M, Lambert DG, Salvadori S, Regoli D (2002) $\left[\mathrm{Nphe}^{1}, \mathrm{Arg}^{14}{ }^{\text {,Lys }}{ }^{15}\right]$ Nociceptin- $\mathrm{NH}_{2}$, a novel potent and selective antagonist of the nociceptin/orphanin FQ receptor. Br J Pharmacol 136:303-311.

Candeletti S, Ferri S (2000) Effects of an antisense oligonucleotide to pronociceptin and long-term prevention of morphine actions by nociceptin. Peptides 21:1119-1124.

Chiodo L, Bunney B (1984) Effects of dopamine antagonists on midbrain dopamine cell activity. In: Catecholamines: neuropharmacology and central nervous system - theoretical aspects (Usdin E, ed), pp 369-391. New York: Liss.

Cox BM, Chavkin C, Christie MJ, Civelli O, Evans C, Hamon MD, Hoellt V, Kieffer B, Kitchen I, Mcknight AT, Meunier JC, Portoghese PS (2000) Opioid receptors. In: The IUPHAR compendium of receptor characterization and classification (Girdlestone D, ed), pp 321-333. London: IUPHAR Media.

Devine DP, Taylor L, Reinscheid RK, Monsma Jr FJ, Civelli O, Akil H (1996) Rats rapidly develop tolerance to the locomotor-inhibiting effects of the novel neuropeptide orphanin FQ. Neurochem Res 21:1387-1396.

De Risi C, Piero Pollini G, Trapella C, Peretto I, Ronzoni S, Giardina GA (2001) A new synthetic approach to 1-[3R, 4R)-1-cyclooctylmethyl-3hydroxymethyl-4-piperidyl]-3-ethyl-1,3-dihydro-2H-benzimidazol-2one (J-113397), the first non-peptide ORL-1 receptor antagonist. Bioorg Med Chem 9:1871-1877.

Di Giannuario A, Pieretti S (2000) Nociceptin differentially affects morphine-induced dopamine release from the nucleus accumbens and nucleus caudate in rats. Peptides 21:1125-1130.

Di Giannuario A, Pieretti S, Catalani A, Loizzo A (1999) Orphanin FQ reduces morphine-induced dopamine release in the nucleus accumbens: a microdialysis study in rats. Neurosci Lett 272:183-186.

Flau K, Redmer A, Liedtke S, Kathmann M, Schlicker E (2002) Inhibition of striatal and retinal dopamine release via nociceptin/orphanin FQ receptors. Br J Pharmacol 137:1355-1361.

Gavioli EC, Marzola G, Guerrini R, Bertorelli R, Zucchini S, De Lima TC, Rae GA, Salvadori S, Regoli D, Calò G (2003) Blockade of nociceptin/orphanin FQ-NOP receptor signalling produces antidepressant-like effects: pharmacological and genetic evidences from the mouse forced swimming test. Eur J Neurosci 17:1987-1990.

Guerrini R, Calò G, Bigoni R, Rizzi A, Varani K, Toth G, Gessi S, Hashiba E, Hashimoto Y, Lambert DG, Borea PA, Tomatis R, Salvadori S, Regoli D (2000) Further studies on nociceptin-related peptides: discovery of a new chemical template with antagonist activity on the nociceptin receptor. J Med Chem 43:2805-2813.

Iwamoto ET, Way EL (1977) Circling behavior and stereotypy induced by intranigral opiate microinjections. J Pharmacol Exp Ther 203:347-359.

Jenck F, Wichmann J, Dautzenberg FM, Moreau JL, Ouagazzal AM, Martin JR, Lundstrom K, Cesura AM, Poli SM, Roever S, Kolczewski S, Adam G, Kilpatrick G (2000) A synthetic agonist at the orphanin FQ/nociceptin receptor ORL1: anxiolytic profile in the rat. Proc Natl Acad Sci USA 97:4938-4943.

Kawahara Y, Hesselink MB, van Scharrenburg G, Westerink BH (2004) Tonic inhibition by orphanin FQ/nociceptin of noradrenaline neurotransmission in the amygdala. Eur J Pharmacol 485:197-200.

Kawamoto H, Ozaki S, Itoh Y, Miyaji M, Arai S, Nakashima H, Kato T, Ohta H, Iwasawa Y (1999) Discovery of the first potent and selective small molecule opioid receptor-like (ORL1) antagonist: 1-[(3R, 4R)-1cyclooctylmethyl-3-hydroxymethyl-4-piperidyl]-3-ethyl-1,3-dihydro2H-benzimidazol-2-one (J-113397). J Med Chem 42:5061-5063.

Koizumi M, Midorikawa N, Takeshima H, Murphy NP (2004) Exogenous, but not endogenous nociceptin modulates mesolimbic dopamine release in mice. J Neurochem 89:257-263.
Kuzmin A, Sandin J, Terenius L, Ogren SO (2004) Evidence in locomotion test for the functional heterogeneity of ORL-1 receptors. Br J Pharmacol 141:132-140.

Lacey MG, Mercuri NB, North RA (1987) Dopamine acts on D2 receptors to increase potassium conductance in neurones of the rat substantia nigra zona compacta. J Physiol (Lond) 392:397-416.

Lutfy K, Do T, Maidment NT (2001) Orphanin FQ/nociceptin attenuates motor stimulation and changes in nucleus accumbens extracellular dopamine induced by cocaine in rats. Psychopharmacology (Berl) 154:1-7.

Lutfy K, Khaliq I, Carroll FI, Maidment NT (2002) Orphanin FQ/nociceptin blocks cocaine-induced behavioral sensitization in rats. Psychopharmacology (Berl) 164:168-176.

Maidment NT, Chen Y, Tan AM, Murphy NP, Leslie FM (2002) Rat ventral midbrain dopamine neurons express the orphanin FQ/nociceptin receptor ORL-1. NeuroReport 13:1137-1140.

Manabe T, Noda Y, Mamiya T, Katagiri H, Houtani T, Nishi M, Noda T, Takahashi T, Sugimoto T, Nabeshima T, Takeshima H (1998) Facilitation of long-term potentiation and memory in mice lacking nociceptin receptors. Nature 394:577-581.

Mansour A, Fox CA, Akil H, Watson SJ (1995) Opioid-receptor mRNA expression in the rat CNS: anatomical and functional implications. Trends Neurosci 18:22-29.

Marti M, Guerrini R, Beani L, Bianchi C, Morari M (2002a) Nociceptin/ orphanin FQ receptors modulate glutamate extracellular levels in the substantia nigra pars reticulata. A microdialysis study in the awake freely moving rat. Neuroscience 112:153-160.

Marti M, Mela F, Bianchi C, Beani L, Morari M (2002b) Striatal dopamineNMDA receptor interactions in the modulation of glutamate release in the substantia nigra pars reticulata in vivo: opposite role for D1 and D2 receptors. J Neurochem 83:635-644.

Marti M, Mela F, Ulazzi E, Vaccari E, Beani L, Bianchi C, Morari M (2003a) Nigral NOP receptor stimulation inhibits dopamine release in the dorsolateral striatum and motor behavior in rats. In: Monitoring molecules in neuroscience (Kehr J, Fuke K, Ungerstedt U, Svensson T, eds), pp 327329. Stockholm: Karolinska UP.

Marti M, Stocchi S, Paganini F, Mela F, De Risi C, Calò G, Guerrini R, Barnes TA, Lambert DG, Beani L, Bianchi C, Morari M (2003b) Pharmacological profiles of presynaptic nociceptin/orphanin FQ receptors modulating 5-hydroxytryptamine and noradrenaline release in the rat neocortex. $\mathrm{Br} \mathrm{J}$ Pharmacol 138:91-98.

Matsumoto RR, Brinsfield KH, Patrick RL, Walker JM (1988) Rotational behavior mediated by dopaminergic and nondopaminergic mechanisms after intranigral microinjection of specific mu, delta and kappa opioid agonists. J Pharmacol Exp Ther 246:196-203.

McLeod RL, Parra LE, Mutter JC, Erickson CH, Carey GJ, Tulshian DB, Fawzi AB, Smith-Torhan A, Egan RW, Cuss FM, Hey JA (2001) Nociceptin inhibits cough in the guinea-pig by activation of ORL(1) receptors. Br J Pharmacol 132:1175-1178.

Mercuri NB, Calabresi P, Bernardi G (1990) Effects of glycine on neurons in the rat substantia nigra zona compacta: in vitro electrophysiological study. Synapse 5:190-200.

Mercuri NB, Bonci A, Calabresi P, Stefani A, Bernardi G (1995) Properties of the hyperpolarization-activated cation current Ih in rat midbrain dopaminergic neurones. Eur J Neurosci 7:462-469.

Meunier JC, Mollereau C, Toll L, Suaudeau C, Moisand C, Alvinerie P, Butour JL, Guillemot JC, Ferrara P, Monsarrat B, Mazarguil H, Vassart G, Parmentier M, Costentin J (1995) Isolation and structure of the endogenous agonist of opioid receptor-like $\mathrm{ORL}_{1}$ receptor. Nature 377:532-535.

Mogil JS, Pasternak GW (2001) The molecular and behavioral pharmacology of the orphanin FQ/nociceptin peptide and receptor family. Pharmacol Rev 53:381-415.

Morelli M, Di Chiara G (1985) Non-dopaminergic mechanisms in the turning behavior evoked by intranigral opiates. Brain Res 341:350-359.

Murphy NP, Maidment NT (1999) Orphanin FQ/nociceptin modulation of mesolimbic dopamine transmission determined by microdialysis. J Neurochem 73:179-186.

Murphy NP, Ly HT, Maidment NT (1996) Intracerebroventricular orphanin FQ/nociceptin suppresses dopamine release in the nucleus accumbens of anaesthetized rats. Neuroscience 75:1-4.

Murphy NP, Lam HA, Chen Z, Pintar JE, Maidment NT (2002) Heroin- 
induced locomotion and mesolimbic dopamine release is unchanged in mice lacking the ORL.1 receptor gene. Brain Res 953:276-280.

Nishi M, Houtani T, Noda Y, Mamiya T, Sato K, Doi T, Kuno J, Takeshima H, Nukada T, Nabeshima T, Yamashita T, Noda T, Sugimoto T (1997) Unrestrained nociceptive response and dysregulation of hearing ability in mice lacking the nociceptin/orphanin FQ receptor. EMBO J 16:1858-1864.

Noda Y, Mamiya T, Nabeshima T, Nishi M, Higashioka M, Takeshima H (1998) Loss of antinociception induced by naloxone benzoylhydrazone in nociceptin receptor-knockout mice. J Biol Chem 273:18047-18051.

Norton CS, Neal CR, Kumar S, Akil H, Watson SJ (2002) Nociceptin/orphanin FQ and opioid receptor-like receptor mRNA expression in dopamine systems. J Comp Neurol 444:358-368.

Ozaki S, Kawamoto H, Itoh Y, Miyaji M, Iwasawa Y, Ohta H (2000) A potent and highly selective nonpeptidyl nociceptin/orphanin FQ receptor (ORL1) antagonist: J-113397. Eur J Pharmacol 387:R17-R18.

Paladini CA, Tepper JM (1999) GABA(A) and GABA(B) antagonists differentially affect the firing pattern of substantia nigra dopaminergic neurons in vivo. Synapse 32:165-176.

Paxinos G, Watson C (1982) The rat brain in stereotaxic coordinates. Sydney: Academic.

Pinnock RD (1984) The actions of antipsychotic drugs on dopamine receptors in the rat substantia nigra. Br J Pharmacol 8:631-635.

Polidori C, Calò G, Ciccocioppo R, Guerrini R, Regoli D, Massi M (2000) Pharmacological characterization of the nociceptin receptor mediating hyperphagia: identification of selective antagonist. Psychopharmacology (Berl) 148:430-437.

Pucak ML, Grace AA (1996) Effects of haloperidol on the activity and membrane physiology of substantia nigra dopamine neurons recorded in vitro. Brain Res 713:44-52.

Redrobe JP, Calò G, Regoli D, Quirion R (2002) Nociceptin receptor antagonists display antidepressant-like properties in the mouse forced swimming test. Naunyn Schmiedebergs Arch Pharmacol 365:164-167.

Reinscheid RK, Nothacker HP, Bourson A, Ardati A, Henningsen RA, Bunzow JR, Grandy DK, Langen H, Monsma Jr FJ, Civelli O (1995) Orphanin FQ: a neuropeptide that activates an opioid-like G protein-coupled receptor. Science 270:792-794.

Rizzi A, Bigoni R, Marzola G, Guerrini R, Salvadori S, Regoli D, Calò G (2001) Characterization of the locomotor activity-inhibiting effect of no- ciceptin/orphanin FQ in mice. Naunyn Schmiedebergs Arch Pharmacol 363:161-165.

Rozas G, Guerra MJ, Labandeira-Garcia JL (1997) An automated rotarod method for quantitative drug-free evaluation of overall motor deficits in rat models of parkinsonism. Brain Res Brain Res Protoc 2:75-84.

Rustay NR, Wahlsten D, Crabbe JC (2003) Influence of task parameters on rotarod performance and sensitivity to ethanol in mice. Behav Brain Res 141:237-249.

Shepard PD, Connelly ST (1999) Pertussis toxin lesions of the rat substantia nigra block the inhibitory effects of the gamma-hydroxybutyrate agent, S(-)HA-966 without affecting the basal firing properties of dopamine neurons. Neuropsychopharmacology 21:650-661.

Shieh K, Pan J (1998) Ontogeny of the diurnal rhythm of tuberoinfundibular dopaminergic neuronal activity in peripubertal female rats: possible involvement of cholinergic and opioidergic systems. Neuroendocrinology 68:395-402.

Turski L, Havemann U, Schwarz M, Kuschinsky K (1982) Disinhibition of nigral GABA output neurons mediates muscular rigidity elicited by striatal opioid receptor stimulation. Life Sci 31:2327-2330.

Turski L, Havemann U, Kuschinsky K (1983) The role of the substantia nigra in motility of the rat. Muscular rigidity, body asymmetry and catalepsy after injection of morphine into the nigra. Neuropharmacology 22:1039-1048

Ueda H, Inoue M, Takeshima H, Iwasawa Y (2000) Enhanced spinal nociceptin receptor expression develops morphine tolerance and dependence. J Neurosci 20:7640-7647.

Zaratin PF, Petrone G, Sbacchi M, Garnier M, Fossati C, Petrillo P, Ronzoni S, Giardina GA, Scheideler MA (2004) Modification of nociception and morphine tolerance by the selective opiate receptor-like orphan receptor antagonist (-)-cis-1-methyl-7-[[4-(2,6-dichlorophenyl)piperidin-1yl]methyl]-6,7,8,9-tetrahydro-5H-benzocyclohepten-5-ol (SB-612111). J Pharmacol Exp Ther 308:454-461.

Zaveri N (2003) Peptide and nonpeptide ligands for the nociceptin/orphanin FQ receptor ORL1: research tools and potential therapeutic agents. Life Sci 73:663-678.

Zheng F, Grandy DK, Johnson SW (2002) Actions of orphanin FQ/nociceptin on rat ventral tegmental area neurons in vitro. Br J Pharmacol 136 1065-1071. 